\title{
PENGARUH PROPORSI BERAS SEJAHTERA DAN SAWUT SINGKONG TERHADAP MUTU NASI SAWUT
}

\section{[The Effect of Prosperous Rice and Shredded Cassava Proportion on the Quality of Shredded Cassava Rice]}

\author{
Wiwik Pratiwi, Baiq Rien Handayani*, Nazaruddin \\ Program Studi Ilmu dan Teknologi Pangan, FATEPA, UNRAM \\ Jl. Majapahit No. 58 Mataram \\ *Email: baiqrienhs@unram.ac.id
}

Diterima 21 Oktober 2020 / Disetujui 15 Januari

\begin{abstract}
The purpose of this study was to determine the effect of proportion of "Rastra" (Prosperous Rice) and shredded cassava on the quality of shredded cassava rice. The method used was experimental method in laboratory and designed using Randomized Block Design (RBD) with a single factor i.e. proportion of prosperous rice and shredded cassava. The treatments of rice and shredded cassava proportions were consisted of 100\%: 0\%; $80 \%: 20 \%$; 60\%: $40 \% ; 40 \%: 60 \%$ and $20 \%: 80 \%$. Chemical and organoleptic data were analyzed using analysis of variance (ANOVA) at 5\% significance level using Co-stat software. The significant difference data were tested by a real difference test with honestly significant difference test, while the microbiological data were analyzed with a descriptive method. The results showed that the proportion of prosperous rice and shredded cassava had a significantly different effect on chemical quality (moisture content and ash content) and organoleptic quality (color, taste and texture) but did not significantly affect on organoleptic quality (aroma) and total microbes. $60 \%$ of prosperous rice and $40 \%$ of shredded cassava was recommended as the best proportion to produce shredded cassava rice with characteristic yellowish white, odorless smell, fluffy texture and taste of rice and has a water content of $66.02 \%$, a value of $0.13 \%$ ash and microbiological quality that has met the SNI standard 7388: 2009 with a total microbe of $3.3 \times 10^{5} \mathrm{CFU} / \mathrm{g}$, total mushroom 7,2x10² CFU/g and total coliform $27 \mathrm{MPN} / \mathrm{g}$.
\end{abstract}

Keywords: Prosperous Rice, Quality, Proportion, Shredded Cassava

\begin{abstract}
ABSTRAK
Tujuan penelitian ini adalah untuk mengetahui pengaruh proporsi beras sejahtera dan sawut singkong terhadap komponen mutu nasi sawut. Metode yang digunakan dalam penelitian ini adalah metode eksperimental yang dilaksanakan di Laboratorium dan dirancang menggunakan Rancangan Acak Kelompok (RAK) dengan satu faktor yaitu proporsi beras sejahtera dan sawut (100\%:0\%; $80 \%: 20 \%$; 60\%:40\%; 40\%:60\% dan 20\%:80\%). Data hasil pengamatan kimia dan organoleptik dianalisis dengan analisis keragaman (ANOVA) pada taraf nyata $5 \%$ dengan menggunakan software Co-Stat dan diuji lanjut dengan $\mathrm{BNJ}$, sedangkan data hasil pengamatan mikrobiologi dianalisis menggunakan metode deskriptif. Hasil penelitian menunjukkan bahwa proporsi beras sejahtera dan sawut singkong memberikan pengaruh yang berbeda nyata terhadap mutu kimia (kadar air dan kadar abu nasi) dan mutu organoleptik (warna, rasa dan tekstur) namun tidak berpengaruh nyata pada mutu organoleptik (aroma) dan mutu mikrobiologi (total mikroba). Perlakuan proporsi beras sejahtera dan sawut singkong (60\%:40\%) merupakan perlakuan terbaik karena menghasilkan nasi sawut dengan warna putih kekuningan, aroma tidak berbau apek, tekstur pule, berasa nasi serta memiliki kadar air 66,02\%, nilai kadar abu 0,13\% serta mutu mikrobiologi yang telah

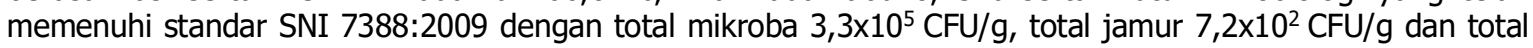
koliform $27 \mathrm{MPN} / \mathrm{g}$.
\end{abstract}

Kata Kunci: Beras Sejahtera, Mutu, Proporsi, Sawut Singkong.

\section{PENDAHULUAN}

Beras merupakan bahan makanan pokok bagi sebagian besar masyarakat Indonesia. Peranan beras yang begitu penting, menjadikan kebutuhan akan beras terus meningkat setiap tahunnya.
Perhitungan berdasarkan pendekatan neraca bahan makanan agregat (apparent consumption) menunjukkan bahwa kebutuhan beras per kapita adalah sekitar $139,15 \mathrm{~kg} / \mathrm{kapita} / \mathrm{th}$. Nusa tenggara barat merupakan daerah yang dikenal sebagai 
Versi Online:

http://Www.profood.unram.ac.id/index.php/profood e-ISSN: 2443-3446

salah satu daerah lumbung beras nasional. Meskipun produksi beras nasional saat ini cukup banyak, namun dikhawatirkan tidak dapat memenuhi kebutuhan beras nasional.

Program RASTRA (Beras Sejahtera) adalah program nasional yang bersentuhan langsung dengan masyarakat. Melalui program ini pemerintah memberikan bantuan kepada masyarakat untuk mendapatkan hak atas pangan. beras sejahtera yang diberikan kepada masyarakat ekonomi menengah kebawah umumnya dijual dengan harga yang murah. Namun harga murah tidak dapat menjamin kualitas beras yang baik bagi masyarakat. beras sejahtera yang diperoleh dari pemerintah memiliki kualitas yang rendah. Hal ini sesuai dengan penelitian (Junaidi, 2017) melaporkan bahwa beras sejahtera yang diberikan kepada warga memiliki kualitas dan mutu yang cukup buruk, karena menurut warga beras BULOG tidak pulen dan memiliki bau yang tidak sedap.

Menurut Juliano (1994) dalam Loebis, Junaidi dan Susanti (2017) nasi tidak pulen karena tingginya kandungan amilosa sehingga nasi semakin kurang lekat dan semakin keras (pera). beras sejahtera memilki tingkat kepulenan yang rendah dikarenakan penyimpanan beras yang terlalu lama mengakibatkan penurunan kualitas beras yang tidak bisa dihindari mulai dari bau apek hingga berkutu. Oleh karena itu untuk memenuhi kebutuhan masyarakat akan sumber karbohidrat dan perbaikan kualitas beras sejahtera maka diperlukan alternatif sumber karbohidrat antara lain yang berasal dari singkong dalam bentuk sawut. Berdasarkan potensi fisik seperti kesesuaian lahan, iklim, sumber daya manusia, dan tingkat adaptasi teknologi, maka tanaman singkong dapat dibudidayakan di berbagai daerah di Indonesia (BPS, 2013).

Kabupaten Lombok Utara (KLU) merupakan wilayah penghasil singkong terbesar di Nusa Tenggara Barat. Data (BPS NTB, 2015) memperlihatkan 25,39\% produksi singkong NTB. Singkong di wilayah
Pro Food (Jurnal IImu dan Teknologi Pangan)

Vol 6 No. 2 November 2020

ISSN: 2443-1095

tersebut memiliki peluang besar untuk memproduksi singkong dalam jumlah besar setiap tahunnya. Melalui diversifikasi singkong dapat dimanfaatkan sebagai substitusi atau pengganti beras. Pradiptya dan Amam (2019), menyatakan bahwa singkong memiliki kandungan karbohidrat sebesar 38 gram per 100 gram singkong atau setara dengan $12 \%$, sehingga cocok dijadikan makanan pengganti beras atau memperbaiki mutu beras. Diversifikasi dilakukan untuk memenuhi kebutuhan akan karbohidrat karena kebiasaan masyarakat Indonesia dengan pola konsumsi yang memiliki ketergantungan tinggi terhadap beras. Salah satu diversifikasi singkong yaitu dengan memanfaatkan singkong sebagai bahan baku pembuatan sawut singkong.

Sawut singkong merupakan produk intermediate dari singkong yang dapat digunakan sebagai bahan baku dalam substitusi pembuatan nasi sawut guna untuk meningkatkan mutu organoleptik beras sejahtera yang memiliki mutu yang relatif rendah. Berdasarkan hasil program produk MOCAF oleh Handayani, Ridwan dan Syarifuddin (2012) memperlihatkan bahwa proporsi hingga $75 \%$ sawut singkong dan $25 \%$ beras masih diterima oleh kelompok binaaan di Bayan KLU sedangkan Sabri (2013) melaporkan bahwa proporsi sawut singkong $40 \%$ dan beras C4 $60 \%$ memberikan hasil nasi sawut yang terbaik dengan tingkat kesukaan panelis terhadap tekstur (agak suka), aroma (netral), rasa (netral) dan warna (netral) dengan tingkat kepulenan (netral) yang diterima oleh panelis. Hingga saat ini belum pernah dilakukan penelitian pemanfaatan sawut singkong sebagai salah satu pangan untuk substitusi beras sejahtera sebagai upaya dalam meningkatkan mutunya. Oleh karena itu, untuk meningkatkan mutu beras sejahtera dan mengurangi ketergantungan terhadap beras, maka telah dilakukan penelitian tentang Pengaruh Proporsi RASTRA (Beras Sejahtera) dan Sawut Singkong Terhadap Komponen Mutu Nasi Sawut. 
Versi Online:

http://www.profood.unram.ac.id/index.php/profood e-ISSN: 2443-3446

\section{BAHAN DAN METODE}

\section{Bahan}

Bahan baku yang digunakan dalam penelitian ini adalah beras sejahtera diperoleh dari Bulog Divre NTB Mataram. Sawut singkong diperoleh dari produsen tepung MOCAF dari kelompok usaha Mekar Makmur (Desa Akar-Akar, Kecamatan Bayan, Kabupaten Lombok Utara) air (PDAM), aquades, medium Potato Dextrose Agar/PDA (merk OXOID CM0139), medium Plate Count Agar/PCA (merk OXOID CM0325), Lauryl Tryptose Broth/LTB (merk OXOID CM0451), Briliant Grreen Lactose Bile Broth/BGLBB (merk OXOID CM0031) larutan buffer phosphate dan alkohol.

Alat yang digunakan dalam penelitian ini antara lain dandang pengukus ukuran $1 \mathrm{~kg}$ merk Jawa, kompor gas merk Rinnai, inkubator (Memmert, Jerman) laminar flow (Streamline, Jerman), blue tip, vortex, cawan petri (Anumbra, Jerman), timbangan analitik (Kern, Jerman), lampu bunsen, drigalski, oven (Memmert, Jerman), Hot plate (Heidolph, Jerman dan IEC, Australia), shaker (Heidolph, Jerman), beaker glass, kertas saring dan alat laboratorium lainnya.

\section{Metode}

Metode penelitian yang digunakan adalah metode eksperimental yang dilaksanakan di laboratorium.

\section{Pelaksanaan Penelitian:}

1. Persiapan Bahan Baku

a. Persiapan Beras

Bahan baku beras yang digunakan adalah beras sejahtera yang diperoleh dari Bulog Divre NTB Mataram.

b. Persiapan Sawut Singkong

Bahan baku yang digunakan adalah sawut singkong yang diperoleh dari produsen tepung mocaf dari kelompok Usahan Mekar Makmur, Desa Akar-Akar, Kecamatan Bayan, Kabupaten Lombok Utara.

2. Sortasi
Pro Food (Jurnal Ilmu dan Teknologi Pangan) Vol 6 No. 2 November 2020 ISSN: 2443-1095

Sortasi bertujuan untuk menghilangkan kotoran dan benda asing yang ada pada beras dan sawut singkong, sehingga diperoleh beras dan sawut singkong yang baik dan bersih dari benda asing.

3. Penimbangan

Persiapan proporsi nasi sawut dilakukan dengan mengikuti penimbangan beras sejahtera + sawut singkong dengan jumlah berat total bahan baku 300 gram. Masing-masing berat bahan baku beras sejahtera + sawut singkong $(300 \mathrm{gr}+0 \mathrm{gr} ; 240 \mathrm{gr}$ $+60 \mathrm{gr} ; 180 \mathrm{gr}+120 \mathrm{gr} ; 120 \mathrm{gr}+180$ gr; $60 \mathrm{gr}+240 \mathrm{gr}$ dan $0 \mathrm{gr}+300 \mathrm{gr})$.

4. Pemasakan Beras

Pemasakan beras sampai dengan setengah matang dilakukan dengan menggunakan panci merk Jawa dengan kapasitas 1 liter selama \pm 10 - 15 menit, dengan perbandingan beras $(\mathrm{gr})+$ air (ml) adalah $(300 \mathrm{gr}+550 \mathrm{ml} ; 240 \mathrm{gr}+$ $490 \mathrm{ml} ; 180 \mathrm{gr}+430 \mathrm{ml} ; 120 \mathrm{gr}+370$ $\mathrm{ml}$ dan $60 \mathrm{gr}+310 \mathrm{ml}$ ), ini bertujuan untuk mempermudah selama proses pencampuran dengan sawut singkong yang telah direndam.

5. Perendaman Sawut Singkong

Proses perendaman sawut singkong dilakukan selama 30 menit, ini bertujuan untuk melunakkan tekstur sawut singkong supaya mempermudah selama proses pencampuran dengan beras yang sudah dimasak setengah matang.

6. Penirisan

Sawut singkong yang tekah direndam kemudian ditiriskan untuk mengurangi kadar airnya agar mempermudah proses selanjutnya.

7. Pencampuran

Beras sejahtera yang sudah dimasak setengah matang dicampur dengan sawut singkong yang telah direndam sesuai dengan perlakuan dengan berat masing-masing. Pencampuran dilakukan pada dandang merk Jawa secara terus menerus sampai diperoleh campuran yang merata. 
Versi Online:

http://www.profood.unram.ac.id/index.php/profood e-ISSN: 2443-3446

8. Pemasakan

Campuran beras sejahtera dengan sawut singkong selanjutnya dimasak dengan menggunakan dandang merk Jawa selama 20-30 menit.

9. Pengangkatan dan Pendinginan

Setelah nasi sawut matang kemudian diangkat dan dikeluarkan dari dandang lalu didinginkan.

\section{Rancangan Percobaan dan Analisis Data}

Rancangan percobaan yang digunakan adalah Rancangan Acak Kelompok (RAK) menggunakan satu faktor yaitu proporsi beras sejahtera dengan sawut singkong yang terdiri atas 6 perlakuan yaitu N1 (100\% : 0\%), N2 (80\% : 20\%), N3 (60\% : 40\%), N4 (40\%: 60\%), N5 (20\%: $80 \%)$ dan N6 (0\%: 100\%).

Masing-masing perlakuan tersebut diulang sebanyak 3 kali hingga diperoleh 18 unit percobaan. Data hasil pengamatan dianalisa dengan ANOVA (Analysis of variance) pada taraf nyata $5 \%$. Bila terdapat perlakuan yang beda nyata maka dilanjutkan dengan uji lanjut Beda Nyata Jujur (BNJ).

\section{HASIL DAN PEMBAHASAN}

Parameter mutu nasi sawut singkong yang diuji pada penelitian ini terdiri dari mutu kimia, mutu organoleptik dan mutu mikrobiologi. Adapun penjelasannya sebagai berikut:

\section{Mutu Kimia}

\section{a. Kadar Air}

Kadar air adalah persentase kandungan air suatu bahan dapat dinyatakan berdasarkan berat basah atau berat kering. Hubungan pengaruh proporsi beras sejahtera dan sawut singkong terhadap kadar air nasi sawut dapat dilihat pada Gambar 1.

Berdasarkan Gambar 1 menunjukkan bahwa perlakuan proporsi beras sejahtera dan sawut singkong memberikan pengaruh yang berbeda nyata terhadap kadar air nasi sawut pada proporsi (100\%:0\%; 80\%:20\%; 60\%:40\%； $20 \%: 80 \%$ dan 0\%:100\%)
Pro Food (Jurnal Ilmu dan Teknologi Pangan) Vol 6 No. 2 November 2020 ISSN: 2443-1095

dengan nilai kadar air berturut-turut sebesar $63,90 \% ; 66,08 \% ; 66,74 \% ; 67,03 \% ; 64,80 \%$ dan $59,51 \%$. Dalam pembuatan nasi sawut dilakukan proses pemasakan pada suhu \pm 80 ${ }^{\circ} \mathrm{C}$ sehingga pada kondisi ini sebagian pati akan tergelatinisasi. Menurut Yadav dan Jindal (2007) pada suhu gelatinisasi pati kemampuan absorpsi air pada beras dan produk turunan dari umbi-umbian ditentukan oleh kadar amilosa. Semakin tinggi amilosa kecepatan absorpsi air semakin tinggi pula.

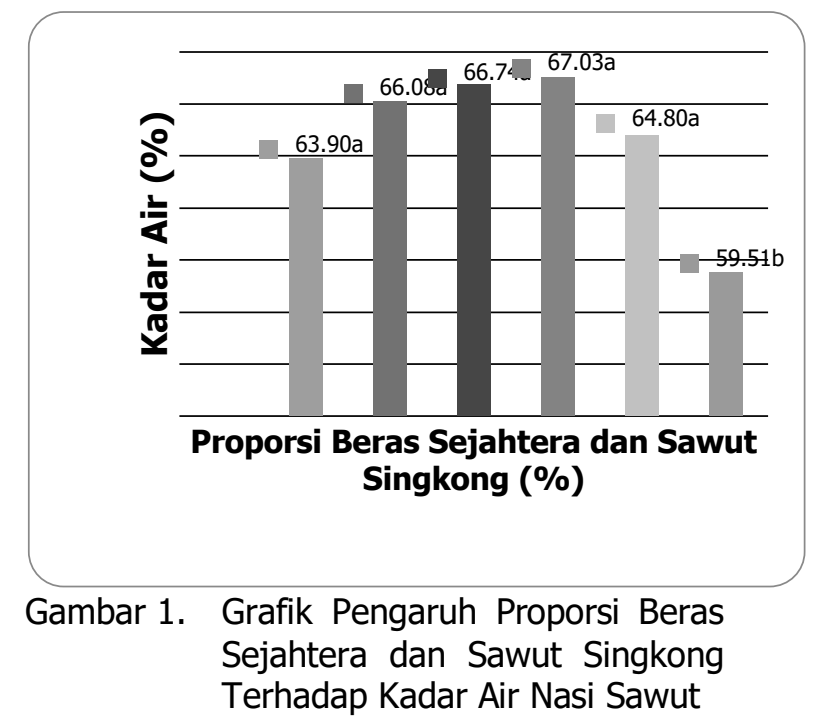

Nilai kadar air tertinggi nasi sawut diperoleh pada perlakuan proporsi beras sejahtera dan sawut singkong (40\%:60\%) yaitu sebesar $67,03 \%$. Nilai kadar air tertinggi yang diperoleh pada nasi sawut dipengaruhi oleh kandungan amilosa sawut singkong menurut Purba (2010) yaitu sebesar $34,75 \%$ sedangkan kadar amilopektinnya adalah sebesar 39,55\%, dimana kandungan amilosa yang tinggi pada sawut singkong dapat menyebabkan nasi sawut memiliki kemampuan untuk mengabsorpsi air yang lebih tinggi.

Nilai kadar nasi sawut terendah terdapat pada perlakuan penambahan proporsi beras sejahtera dan sawut singkong (0\%:100\%) yakni sebesar $59,51 \%$. Nilai kadar air terendah yang diperoleh pada nasi sawut dipengaruhi oleh kandungan amilosa pada sawut singkong yakni sebesar $34,75 \%$. Menurut Yadav dan Jindal (2007), kecepatan absorpsi air meningkat dengan meningkatnya 
Versi Online:

http://www.profood.unram.ac.id/index.php/profood e-ISSN: 2443-3446

kadar amilosa. Namun apabila absorpsi air sudah mencapai maksimum, bahan pangan dengan amilosa rendah justru kadar airnya lebih tinggi. Hasil yang diperoleh sesuai dengan hasil penelitian Sabri (2013) bahwa kadar air nasi sawut semakin meningkat seiring dengan bertambahnya persentase sawut singkong yang digunakan dimana kadar air nasi sawut meningkat karena banyaknya air yang dapat diserap oleh sawut singkong.

Nilai kadar air ditentukan oleh kandungan amilosa pada bahan dimana kandungan amilosa sawut singkong menurut Purba (2017) yaitu sebesar $34,75 \%$ dan menurut Luna et al. (2015) menyatakan bahwa kandungan amilosa pada beras yaitu $>20 \%$. Kandungan amilosa akan menentukan seberapa banyak air yang diserap selama proses gelatinisasi dimana menurut Yadav dan Jindal (2017) menyatakan bahwa semakin tinggi kandungan amilosa pada bahan maka daya penyerapan air juga semakin tinggi sedangkan pada perlakuan proporsi beras sejahtera dan sawut singkong (0\%:100\%) diperoleh nilai kadar air terendah sebesar $59,91 \%$, hal ini disebabkan karena beras sejahtera telah diberikan perlakuan berupa pemasakan setengah matang sebelum dilakukan pengukusan sehingga terjadi proses gelatinisasi dan terjadi penyerapan air yang menyebabkan granula pati pecah sedangkan sawut singkong hanya diberikan perlakuan berupa perendaman sebelum dilakukan pengukusan sehingga tidak terjadi proses gelatinisasi pada sawut singkong selama proses perendaman. Semakin lama waktu perendaman pada bahan pangan yang mengandung pati maka kadar amilosa bahan akan semakin menurun. Proses fermentasi sawut singkong juga dapat mempengaruhi kadar air, karena kadar air digunakan oleh Lactobacillus sehingga kadar air pada bahan dapat berkurang. Kadar air menurun dengan semakin bertambahnya lama fermentasi, ini disebabkan terjadi degradasi pati dalam bahan yang disertai dengan pembentukan gula-gula sederhana dan pelepasan air.
Pro Food (Jurnal Ilmu dan Teknologi Pangan) Vol 6 No. 2 November 2020 ISSN: 2443-1095

Adapun semakin lama proses pemanasan maka kadar air akan semakin rendah. Kadar air juga bisa dipengaruhi oleh jenis varietas singkong itu sendiri dan juga bisa dipengaruhi oleh curah hujan ditempat penanaman (Amanu dan Wahono, 2014).

\section{b. Kadar Abu}

Abu merupakan residu organik setelah bahan dibakar pada suhu tinggi (diabukan). Hubungan proporsi beras sejahtera dan sawut singkong terhadap parameter kimia kadar abu nasi sawut singkong dapat dilihat pada Gambar 2.

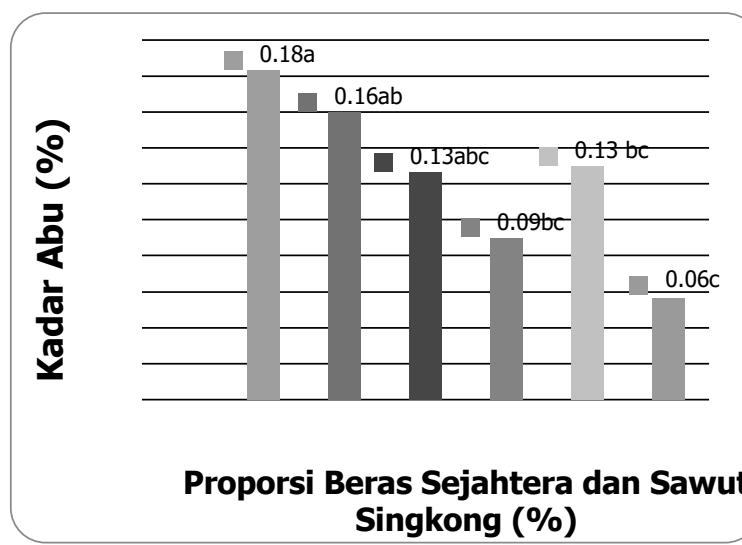

Gambar 2. Grafik Pengaruh Proporsi Beras Sejahtera dan Sawut Singkong Terhadap Kadar Abu Nasi Sawut

Berdasarkan Gambar 2, terlihat bahwa semakin tinggi proporsi beras sejahtera dan sawut singkong maka akan semakin menurun kadar abu nasi sawut. Kadar abu tertinggi diperoleh pada perlakuan proporsi beras sejahtera dan sawut singkong (100\%:0\%) sebesar 0,18\% dan nilai kadar abu terendah pada perlakuan proporsi beras sejahtera dan sawut singkong (0\%:100\%) sebesar $0,06 \%$. Kandungan mineral yang terdapat pada sawut singkong menurut Salim (2011) yaitu sebesar 0,4\% dengan kadar abu sebesar 1\% dan Houston (1970) melaporkan bahwa kandungan mineral yang terdapat pada beras sejahtera yaitu sebesar 3\% dengan kadar abu sebesar $1 \%$. Proses pengolahan nasi sawut dilakukan dengan merendam sawut singkong selama 30 menit.

Menurut Andarwulan, Kusnandar dan Herawati (2011) pengaruh pengolahan pada bahan dapat mempengaruhi ketersediaan 
Versi Online:

http://www.profood.unram.ac.id/index.php/profood e-ISSN: 2443-3446

mineral bagi tubuh. Penggunaan air pada proses pencucian, perendaman dan perebusan dapat mengurangi ketersediaan mineral karena mineral akan larut oleh air yang digunakan. Oleh karena itu, jika dilihat dari perbandingan proporsi beras sejahtera dan sawut singkong yang digunakan dalam penelitian ini adalah, semakin tinggi proporsi sawut singkong dan semakin rendah proporsi beras sejahtera maka akan menghasilkan nilai kadar abu nasi sawut yang semakin rendah. Nilai kadar abu yang diperoleh sesuai dengan hasil penelitian Sabri (2013) yang melaporkan bahwa semakin besar proporsi sawut singkong maka akan semakin menurun kadar abu nasi sawut.

\section{Mutu Organoleptik}

Pengujian organoleptik bertujuan untuk mengetahui sampai sejauh mana tingkat penerimaan panelis (konsumen) terhadap produk nasi sawut yang dihasilkan.

\section{a. Warna}

Penentuan mutu suatu bahan pangan secara visual faktor warna lebih dahulu dan sangat menentukan penerimaan konsumen (Winarno, 2002). Hubungan pengaruh proporsi beras sejahtera dan sawut singkong terhadap warna dari nasi sawut baik secara hedonik dapat dilihat pada Gambar 3.

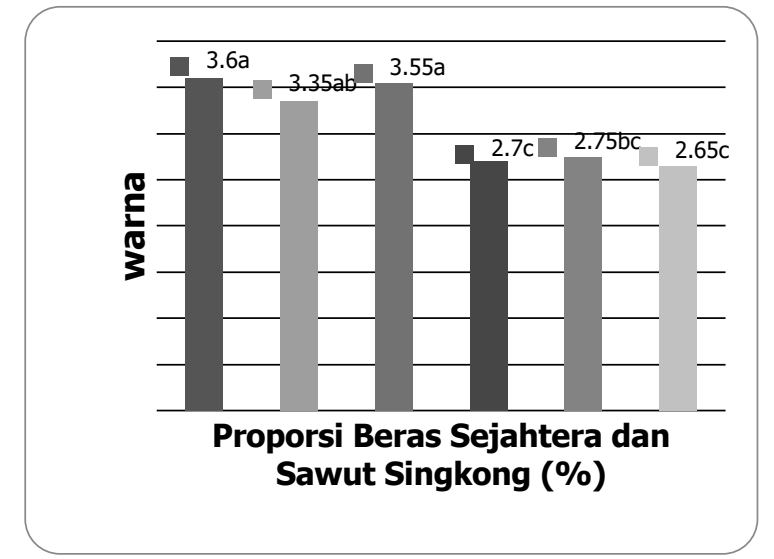

Gambar 3. Grafik Pengaruh Proporsi Beras Sejahtera dan Sawut Singkong Terhadap Parameter Warna Nasi Sawut Secara Hedonik

Berdasarkan Gambar 3 dapat dilihat bahwa warna pada nasi sawut dengan proporsi beras sejahtera dan sawut singkong
Pro Food (Jurnal Ilmu dan Teknologi Pangan)

Vol 6 No. 2 November 2020

ISSN: 2443-1095

(100\%:0\%) menunjukkan hasil yang tidak berbeda nyata secara hedonik pada perlakuan proporsi beras sejahtera dan sawut singkong (80\%:20\% dan 60\%:40\%) dengan rentang nilai 3,6-3,55 dengan kriteria suka, namun berbeda nyata dengan perlakuan proporsi beras sejahtera dan sawut singkong (40\%:60\%; 20\%:80\% dan 0\%:100\%) rentang nilai 2,75-2,65 dengan kriteria agak suka. Hal ini disebabkan karena penambahan proporsi beras sejahtera pada pembuatan nasi sawut dapat menghasilkan warna nasi sawut yang berwarna putih secara skoring sedangkan semakin tinggi proporsi sawut singkong yang digunakan maka secara skoring nasi sawut akan berwarna putih kekuningan. Warna nasi sawut singkong berdasarkan semua perlakuan, dapat dilihat pada Gambar 4.

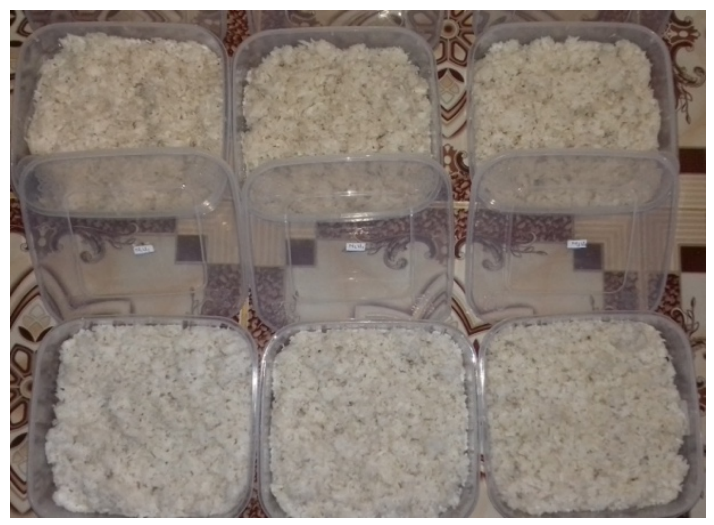

Gambar 4. Nasi Sawut

Nasi sawut dengan penambahan proporsi beras sejahtera dan sawut singkong (60\%:40\%) masih dapat mempertahankan warna nasi sawut dengan kriteria warna putih dan nilai sebesar 3,55. Hal ini sesuai dengan pendapat Tandrianto et al, (2014) yang menyatakan bahwa semakin lama waktu fermentasi maka sawut yang dihasilkan akan cenderung semakin putih. Menurut Sabri (2013) skor organoleptik warna yang diperoleh nasi sawut dengan perlakuan beras sejahtera dan sawut singkong (60\%:40\%) masih bisa diterima oleh panelis dimana hal tersebut disebabkan oleh warna yang ditimbulkan dari bahan yang digunakan sebagai bahan baku dalam pembuatan nasi sawut. Oleh karena itu, hasil 
Versi Online:

http://www.profood.unram.ac.id/index.php/profood e-ISSN: 2443-3446

yang diperoleh sesuai dengan hasil penelitian Sabri (2013) melaporkan bahwa semakin tinggi proporsi sawut singkong yang ditambahkan maka akan semakin menurun kesukaan panelis terhadap warna nasi sawut.

\section{b. Aroma}

Aroma dapat didefinisikan sebagai sesuatu yang dapat diamati dengan indera pembau. Dalam industri pangan, pengujian terhadap aroma dianggap penting karena dengan cepat dapat memberikan hasil penilaian terhadap produk tentang diterima atau tidaknya produk tersebut (Kartika, 1988).

Aroma pada nasi sawut dengan proporsi beras sejahtera dan sawut singkong menunjukkan hasil yang tidak berbeda nyata secara hedonik pada perlakuan proporsi beras sejahtera dan sawut singkong (100\%:0\%; $\quad 80 \%: 20 \%$, 60\%:40\%; 40\%:60\%; $80 \%: 20 \%$ dan 0\%:100\%) dengan rentang nilai 2,85-3,45 dengan kriteria agak suka. Hal ini disebabkan karena penambahan proporsi sawut singkong pada pembuatan nasi sawut dapat menghasilkan aroma nasi sawut yang agak berbau apek sampai tidak berbau apek secara skoring.

Nasi sawut dengan proporsi beras sejahtera dan sawut singkong (60\%:40\%) menghasilkan aroma nasi sawut tertinggi secara hedonik dengan nilai 3,45 (agak suka). Hal ini sesuai dengan hasil peneltian Sabri (2013) adanya perbedaan antar perlakuan terhadap aroma nasi sawut, namun antar perlakuan tersebut terdapat perlakuan yang berdekatan yang tidak berbeda nyata yang disebabkan karena walaupun terjadi perbedaan aroma antar perlakuan, namun proporsi sawut singkong yang digunakan pada lingkup penelitian ini tidak terlalu cukup tinggi sehingga menyebabkan aroma nasi sawut antar perlakuan tidak berbeda nyata. Bau apek yang dihasilkan oleh beras sejahtera disebabkan karena beras sejahtera disimpan dalam jangka waktu yang lama. Selain itu, proses fermentasi pada pembuatan sawut singkong dapat menyebabkan perubahan karakteristik tepung serta akan dapat
Pro Food (Jurnal Ilmu dan Teknologi Pangan) Vol 6 No. 2 November 2020 ISSN: 2443-1095

menghasilkan aroma dan citarasa khas yang menutupi aroma dan citarasa ubi kayu yang cenderung tidak menyenangkan (Amanu dan Wono, 2014).

\section{c. Tekstur}

Tekstur nasi ditentukan berdasarkan kandungan amilosa dan amilopektin merupakan komponen utama penyusun pati. Komposisi kedua komponen tersebut menentukan karakteristik nasi. Hubungan proporsi beras sejahtera dan sawut singkong terhadap organoleptik tekstur atau kepulenan nasi sawut secara hedonik dapat dilihat pada Gambar 5.

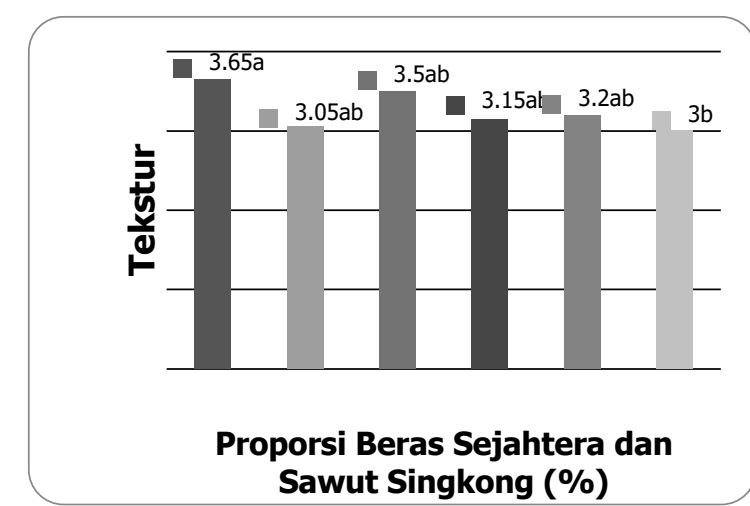

Gambar 5. Grafik Pengaruh Proporsi Beras Sejahtera dan Sawut Singkong Terhadap Parameter Tekstur Nasi Sawut Secara Hedonik

Berdasarkan Gambar 5 terlihat bahwa hubungan proporsi beras sejahtera dan sawut singkong memberikan pengaruh yang tidak berbeda nyata secara hedonik terhadap tekstur nasi sawut pada perlakuan proporsi beras sejahtera dan sawut singkong (100\%) dengan perlakuan proporsi beras sejahtera dan sawut singkong (80\%:20\%; 60\%:40\%; 40\%:60\% dan 20\%:80\%), namun berbeda nyata dengan perlakuan proporsi beras sejahtera dan sawut singkong (0\%:100\%) dengan rentang nilai sebesar 3-3,65 dan kriteria agak suka sampai suka. Hal ini disebabkan karena penambahan proporsi beras sejahtera pada pembuatan nasi sawut dapat menghasilkan tekstur nasi sawut yang pulen secara skoring sehingga disukai oleh panelis. 
Kandungan amilosa pada beras sejahtera dapat menghasilkan nasi sawut yang pulen karena kandungan pati beras sejahtera lebih rendah jika dibandingkan dengan kandungan pati sawut singkong yang mengandung $90 \%$ pati. Oleh karena itu, nasi sawut dengan proporsi beras sejahtera dan sawut singkong (100\%:0\%) menghasilkan tekstur nasi sawut tertinggi secara hedonik dengan nilai 3,65 dan kriteria suka, sedangkan proporsi beras sejahtera dan sawut singkong (0\%:100\%) menghasilkan tekstur nasi sawut terendah dengan nilai 2,7 (agak suka). Hasil penelitian yang diperoleh sesuai dengan hasil penelitian Sabri (2013) bahwa hubungan proporsi beras sejahtera dan sawut singkong yang berbeda memberikan pengaruh yang berbeda nyata terhadap organoleptik tekstur nasi sawut.

Menurut Haryadi (2008) menyatakan bahwa granula pati menyerap air dan mengembang ketika panas dan pada suhu tertentu (disebut sebagai suhu gelatinisasi) tercapai, dinding sel granula memecah dan pada pati menjadi kental (gelatin). Hal ini adalah yang seharusnya terjadi selama proses memasak nasi. Adapun pati yang terdapat didalam beras terdiri dari dua jenis yaitu amilosa dan amilopektin. Komposisi amilosa dan amilopektin berbeda dalam pati berbagai bahan makanan. Menurut Luna et al., (2015) bahwa kandungan amilosa memiliki pengaruh signifikan terhadap retrogradasi pati dan sifat tekstur nasi. Nasi dengan kandungan amilosa tinggi mudah untuk mengalami retrogradasi, sedangkan amilosa rendah lambat beretrogradasi. Semakin tinggi kandungan amilosa beras maka waktu rehidrasi nasi instan semakin cepat. Dari hal tersebut, berarti bahwa pada beras semakin kecil kandungan amilosa atau semakin tinggi kandungan amilopektinnya, semakin pulen (lekat) nasi yang diperoleh.

\section{d. Rasa}

Rasa merupakan salah satu parameter organoleptik yang dapat diuji dengan menggunakan indera pencicipan yaitu lidah terhadap suatu produk. Hubungan proporsi beras sejahtera dan sawut singkong terhadap organoleptik rasa nasi sawut dapat dilihat pada Gambar 6.

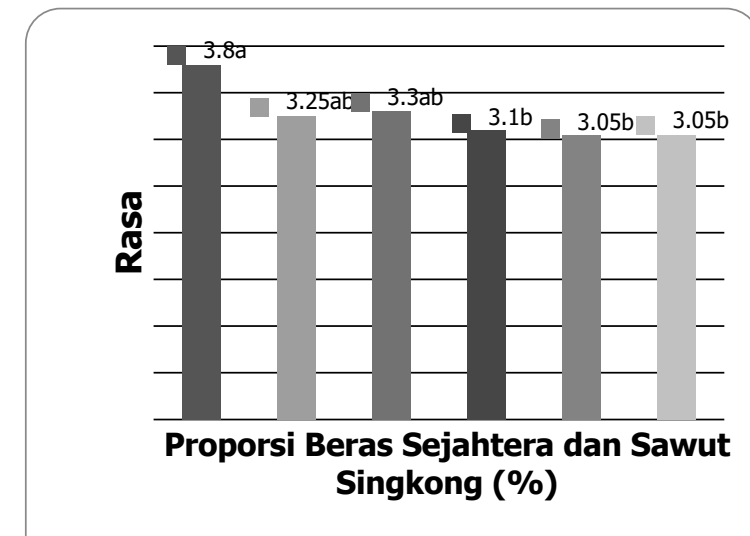

Gambar 6. Grafik Pengaruh Proporsi Beras Sejahtera dan Sawut Singkong Terhadap Parameter Rasa Nasi Sawut Secara Hedonik

Berdasarkan Gambar 6 terlihat bahwa hubungan proporsi beras sejahtera dan sawut singkong memberikan pengaruh yang tidak berbeda nyata secara hedonik terhadap rasa nasi sawut pada perlakuan proporsi beras sejahtera dan sawut singkong (100\%:0\%) dengan proporsi beras sejahtera dan sawut singkong (80\%:20\% dan $60 \%: 40 \%$ ), namun berbeda nyata dengan perlakuan proporsi beras sejahtera dan sawut singkong (40\%:60\%; 20\%:80\% dan $0 \%: 100 \%)$ dengan rentang nilai sebesar 3,0-3,8 dan kriteria agak suka sampai suka. Hal ini disebabkan karena penambahan proporsi beras sejahtera pada pembuatan nasi sawut dapat menghasilkan rasa nasi sawut yang berasa nasi secara skoring sehingga masih bisa diterima dan disukai secara organoleptik oleh panelis.

Nasi sawut dengan proporsi beras sejahtera dan sawut singkong (100\%:0\%) menghasilkan rasa nasi sawut tertinggi secara hedonik dengan nilai 3,8 dan kriteria suka, sedangkan proporsi beras sejahtera dan sawut singkong (0\%:100\%) menghasilkan tekstur nasi sawut terendah dengan nilai 3,0 (agak suka). Hal ini dikarenakan oleh kebiasaan masyarakat yang belum terbiasa dengan rasa nasi sawut, sehingga tingkat kesukaan panelis terhadap rasa nasi sawut semakin menurun seiring 
Versi Online:

http://www.profood.unram.ac.id/index.php/profood e-ISSN: 2443-3446

dengan bertambahnya proposi sawut singkong yang digunakan. Hasil yang diperoleh sesuai dengan hasil penelitian Sabri (2013) yang menyatakan bahwa proporsi beras sejahtera dan sawut singkong yang berbeda memberikan pengaruh yang berbeda nyata terhadap organoleptik rasa nasi sawut dimana semakin tinggi proporsi sawut singkong, maka akan semakin menurun kesukaan panelis terhadap rasa nasi sawut.

\section{Mutu Mikrobiologi}

Pertumbuhan mikroba pada produk pangan sangat mempengaruhi mutu dan daya simpan produk pangan.

\section{a. Total Mikroba}

Pertumbuhan mikroba pada produk pangan sangat mempengaruhi mutu dan daya simpan produk pangan tersebut. Adanya kontaminasi mikroorganisme dalam bahan pangan dapat menyebabkan kerusakan dan masa simpan menjadi lebih singkat. Adapun untuk jumlah total mikroba pada nasi sawut dapat dilihat pada Tabel 1.

Tabel 1. Purata Pengaruh Proporsi Beras Sejahtera dan Sawut Singkong pada Nasi Sawut Terhadap Jumlah Total Mikroba

\begin{tabular}{cc}
\hline $\begin{array}{c}\text { Proporsi Rastra dan } \\
\text { Sawut Singkong (\%) }\end{array}$ & $\begin{array}{c}\text { Purata Total } \\
\text { Mikroba } \\
\text { (CFU/g) }\end{array}$ \\
\hline $100: 0$ & $1,4 \times 10^{5}$ \\
\hline $80: 20$ & $5,5 \times 10^{5}$ \\
\hline $60: 40$ & $3,3 \times 10^{5}$ \\
\hline $40: 60$ & $1,9 \times 10^{5}$ \\
\hline $20: 80$ & $1,0 \times 10^{5}$ \\
\hline $0: 100$ & $3,0 \times 10^{5}$ \\
\hline
\end{tabular}

Berdasarkan Tabel 1 maka dapat diketahui bahwa perlakuan proporsi beras sejahtera dan sawut singkong memberikan pengaruh yang tidak berbeda nyata terhadap total mikroba nasi sawut singkong. Jumlah total mikroba yang didapatkan pada setiap perlakuan proporsi beras sejahtera dan sawut singkong (100\%:0\%; 80\%:20\%; 60\%:40\%； 40\%:60\%; 20\%:80\% dan 0\%:100\%) secara beturut-turut sebesar 1,4 $\times 10^{5} \mathrm{CFU} / \mathrm{gram}, 5,5 \times 10^{5} \mathrm{CFU} / \mathrm{gram}, 3,3 \times$
Pro Food (Jurnal Ilmu dan Teknologi Pangan)

Vol 6 No. 2 November 2020

ISSN: 2443-1095

$10^{5} \mathrm{CFU} / \mathrm{gram}, 1,9 \times 10^{5} \mathrm{CFU} / \mathrm{gram}, 1,0 \times$ $10^{5} \mathrm{CFU} / \mathrm{gram}$ dan $3,0 \times 10^{5} \mathrm{CFU} / \mathrm{gram}$. Berdasarkan jumlah total mikroba yang diperoleh, maka dapat diketahui bahwa jumlah mikroba yang terdapat pada nasi sawut telah memenuhi standar mutu nasi menurut SNI 7388:2009 yaitu batas maksimum cemaran mikroba pada produk makanan sebesar $1,0 \times 10^{6} \mathrm{CFU} / \mathrm{gram}$. Masih adanya mikroba diduga disebabkan karena adanya kontaminasi dari bahan, alat pengolahan dan lingkungan penyimpanan nasi sawut yang dilakukan dalam rentang waktu selama \pm 6 jam pada suhu ruang. Dimana pada suhu ruangan dan rentang waktu selama \pm 6 jam dianggap cukup memberikan keadaan dan waktu yang optimal bagi mikroba untuk tumbuh dan membelah diri. Menurut Aminudin dan Habib (2009) waktu generasi adalah selang waktu yang dibutuhkan bagi sel untuk membelah diri atau untuk populasi menjadi dua kali lipat. Mikroorganisme berkembang biak dengan cara membelah diri dari 1 sel tunggal menjadi dua, dua menjadi empat, empat menjadi delapan dan seterusnya. Waktu yang diperlukan untuk pembelahan tersebut berbeda-beda pada tiap-tiap jenis bakteri, tetapi biasanya berkisar antara 15-30 menit pada kondisi yang ideal untuk pembelahan. Menurut Hamdiyani (2012) frekuensi waktu generasi untuk berbagai mikroorganisme yaitu seperti bakteri selama 45 menit, khamir selama 90 menit dan kapang selama 180 menit.

Hasil yang diperoleh sesuai dengan pendapat Aminudin dan Habib (2009) yang menyatakan bahwa kebanyakan mikroorganisme perusak bahan pangan atau makanan mempunyai suhu pertumbuhan optimal seperti suhu pertumbuhan mikroorganisme mesofilik, yaitu pada kisaran temperatur $25^{\circ} \mathrm{C}-30^{\circ} \mathrm{C}$. Dalam suhu ruangan nasi yang disimpan dapat mengalami kerusakan karena pertumbuhan mikroorganisme mesofilik. Mikroorganisme berkembang biak dengan cara membelah diri dari 1 sel tunggal menjadi dua, dua menjadi empat, empat menjadi delapan dan 
Versi Online:

http://www.profood.unram.ac.id/index.php/profood e-ISSN: 2443-3446

seterusnya. Waktu yang diperlukan untuk pembelahan tersebut berbeda-beda pada tiap-tiap jenis bakteri, tetapi biasanya berkisar antara 15-30 menit pada kondisi yang ideal untuk pembelahan.

Selain itu, jumlah pertumbuhan mikroba pada nasi sawut dapat dipengaruhi oleh kadar air nasi sawut dan jumlah mikroba awal pada bahan baku pembuatan nasi sawut yakni beras sejahtera dan sawut singkong. Jumlah kadar air yang terkandung pada setiap perlakuan nasi sawut singkong juga akan menentukan jumlah mikroba yang akan tumbuh. Adapun kadar air beras yaitu sebesar $13 \%$ sedangkan kadar air beras setelah menjadi nasi yaitu sebesar $63,90 \%$. Hal ini sesuai dengan pendapat Winarno (1992) bahwa kandungan air dalam bahan makanan dapat mempengaruhi daya tahan makanan terhadap serangan mikroorganisme yang dinyatakan dalam aktivitas air (aw), yaitu jumlah air bebas yang digunakan oleh mikroba untuk pertumbuhanya, dimana semakin tinggi kadar air yang terkandung dalam bahan pangan maka semakin cepat rusak karena aktivitas mikroorganisme. Sedangkan menurut Aminudin dan Habib (2009) nasi yang dimasak dengan cara dikukus, dimana suhu nasi dari mikroorganisme termofilik berubah menjadi suhu mikroorganisme mesofilik setelah nasi diambil dari tempat pengukusan. Ketika nasi dikukus, bakteri dalam bentuk spora ini tidak mati tetapi berubah bentuk untuk melindungi diri terhadap faktor-faktor luar yang tidak menguntungkan. Segera setelah keadaan luar baik maka pecahlah bungkus spora dan tumbuhlah bakteri aktif lagi.

\section{b. Total Jamur}

Menurut Kusuma (2010) bahwa nasi mengandung jumlah pati yang relatif tinggi. Pati ini dapat dihidrolisis menjadi gula sederhana oleh mikroorganisme khususnya jamur, karena gula sederhana merupakan sumber nutrisi utama bagi mikroorganisme tersebut. Jamur merupakan mikroorganiseme utama yang berperan penting dalam proses pembusukan nasi. Beberapa jenis jamur yang sering ditemukan pada pembusukan
Pro Food (Jurnal Ilmu dan Teknologi Pangan) Vol 6 No. 2 November 2020 ISSN: 2443-1095

nasi adalah Rhizopus stolonifer, Penicilium $s p$, Mucor $s p$ serta juga terdapat Aspergillus $s p$ dan lainnya. Adapun untuk jumlah total jamur pada nasi sawut dapat dilihat pada Tabel 2.

Tabel 2. Analisis Keragaman Pengaruh Proporsi Beras Sejahtera dan Sawut Singkong pada Nasi Sawut Terhadap Jumlah Total Jamur

\begin{tabular}{cc}
\hline $\begin{array}{c}\text { Proporsi Rastra dan } \\
\text { Sawut Singkong (\%) }\end{array}$ & $\begin{array}{c}\text { Purata Total } \\
\text { Kapang } \\
\text { (CFU/g) }\end{array}$ \\
\hline $100: 0$ & $<1,0 \times 10^{2}$ \\
\hline $80: 20$ & $2,1 \times 10^{2}$ \\
\hline $60: 40$ & $7,2 \times 10^{2}$ \\
\hline $40: 60$ & $1,3 \times 10^{3}$ \\
\hline $20: 80$ & $5,9 \times 10^{2}$ \\
\hline $0: 100$ & $3,5 \times 10^{2}$ \\
\hline
\end{tabular}

Berdasarkan Tabel 2 total jamur yang didapatkan pada nasi sawut singkong untuk setiap perlakuan proporsi beras sejahtera dengan sawut singkong (100\%:0\%; 80\%:20\%; 60\%:40\%; 40\%:60\%; 20\%:80\% dan 0\%:100\%) secara beturut-turut sebesar $<1,0 \times 10^{2} \mathrm{CFU} /$ gram, $2,1 \times 10^{2} \mathrm{CFU} / \mathrm{gram}, 7,2 \times 10^{2} \mathrm{CFU} / \mathrm{gram}, 1,3 \times$ $10^{3} \mathrm{CFU} / \mathrm{gram}, 5,9 \times 10^{2} \mathrm{CFU} / \mathrm{gram}$ dan $3,5 \times 10^{2} \mathrm{CFU} / \mathrm{gram}$. Penambahan proporsi sawut singkong pada pembuatan nasi sawut tidak memberikan pengaruh yang berbeda nyata terhadap jumlah total jamur yang diperoleh karena kandungan pati yang terdapat pada sawut singkong dan beras sejahtera sama-sama dalam jumlah yang relatif tinggi.

Jamur tumbuh pada nasi sawut disebabkan oleh kandungan pati yang terdapat pada beras sejahtera dan sawut singkong. Hal ini sesuai dengan pendapat Mizani, Syarif dan Holinesti (2016) yang menyatakan bahwa bahan pangan yang mengandung pati dalam jumlah yang relatif tinggi dapat dihidrolisis menjadi gula sederhana oleh mikroorganisme khususnya jamur. Hal ini dikarenakan gula sederhana merupakan sumber nutrisi utama bagi pertumbuhan jamur perusak bahan pangan. juga dapat mempengaruhi jumlah pertumbuhan jamur pada nasi sawut. 
Versi Online:

http://www.profood.unram.ac.id/index.php/profood e-ISSN: 2443-3446

Berdasarkan SNI 7388:2009 bahwa jumlah jamur yang boleh ada pada produk makanan turunan dari umbi-umbian dan serelia (termasuk beras) sebesar $1 \times 10^{4}$ CFU/gram. Hal ini menunjukkan bahwa semua perlakuan proporsi beras sejahtera dan nasi sawut singkong (100\%:0\%; 80\%:20\%; 60\%:40\%; 40\%:60\%; 20\%:80\% dan 0\%:100\%) pada nasi sawut sudah memenuhi atau sesuai dengan standar SNI.

\section{c. Total Koliform}

Adapun untuk jumlah total koliform pada nasi sawut dapat dilihat pada Tabel 3.

Tabel 3. Analisis Keragaman Pengaruh Proporsi Beras Sejahtera dan Sawut Singkong pada Nasi Sawut Terhadap Jumlah Total Koliform

\begin{tabular}{cc}
\hline $\begin{array}{c}\text { Proporsi Rastra } \\
\text { dan Sawut } \\
\text { Singkong (\%) }\end{array}$ & Nilai MPN/g \\
\hline $100: 0$ & $36->1.100$ \\
\hline $80: 20$ & $36->1.100$ \\
\hline $60: 40$ & 27 \\
\hline $40: 60$ & $1,1->1.100$ \\
\hline $20: 80$ & $9,2-36$ \\
\hline $0: 100$ & $23-35$ \\
\hline
\end{tabular}

Perlakuan proporsi beras sejahtera dan sawut singkong tidak memberikan pengaruh yang berbeda nyata terhadap total koliform nasi sawut. Berdasarkan Tabel 3 hasil pengamatan jumlah bakteri koliform pada nasi sawut dengan proporsi beras sejahtera dan sawut singkong yang berbedabeda. Adapun berdasarkan metode MPN dalam mengidentifikasi bahan pangan yang terindikasi tersanitasi oleh mikroba koliform yang ditandai dengan adanya gelembung gas pada tabung durham dan terbentunya kekeruhan pada media yang digunakan. Menurut standar WHO semua sampel bahan pangan tidak boleh mengandung Escherichia coli dan sebaiknya juga juga bebas dari bakteri koliform.

Perlakuan proporsi beras sejahtera dan sawut singkong tidak memberikan pengaruh yang berbeda nyata terhadap pertumbuhan koliform pada nasi sawut yang artinya penambahan sawut singkong dan
Pro Food (Jurnal Ilmu dan Teknologi Pangan) Vol 6 No. 2 November 2020 ISSN: 2443-1095

beras sejahtera tidak memberikan pengaruh yang nyata terhadap jumlah koliform. Perlakuan proporsi beras sejahtera dengan sawut singkong (100\%:0\%) memiliki jumlah koliform dengan rentang sebesar 36 MPN/gram sampai $>1,100$ MPN/gram sedangkan untuk perlakuan proporsi beras sejahtera dengan sawut singkong (80\%;20\%) memiliki jumlah koliform dengan rentang sebesar $36 \mathrm{MPN} / \mathrm{gram}$ sampai $>1,100 \mathrm{MPN} / \mathrm{gram}$. Pada perlakuan proporsi beras sejahtera dengan sawut singkong (60\%:40\%) memiliki jumlah koliform sebesar $27 \mathrm{MPN} / \mathrm{gram}$. Perlakuan proporsi beras sejahtera dengan sawut singkong (40\%:60\%) memiliki jumlah koliform dengan rentang sebesar 1,1 MPN/gram sampai $>1,100 \mathrm{MPN} / \mathrm{gram}$ dan pada perlakuan proporsi beras sejahtera dengan sawut singkong (20\%:80\%) memiliki jumlah koliform dengan rentang sebesar 9,2 MPN/gram sampai $36 \mathrm{MPN} / g r a m$ serta pada perlakuan proporsi beras sejahtera dengan sawut singkong (0\%:100\%) memiliki jumlah koliform dengan rentang sebesar 23 MPN/gram sampai 35 MPN/gram.

Jumlah koliform yang beragam pada perlakuan proporsi beras sejahtera dan sawut singkong disebabkan oleh berbagai faktor seperti tercemar pada saat penanganan, penggunaan peralatan dan kondisi lingkungan yang tidak higenis. Melakukan penanganan dan pengolahan diruang terbuka yang merupakan sumber pencemaran. Hal ini sesuai dengan pendapat Laluraa et al. (2014) bahwa penggunaan peralatan yang tidak bersih berulang-ulang serta hanya disimpan diruang terbuka dapat memicu terjadinya kontaminasi mikroba. Oleh karena itu, berdasarkan hasil jumlah bakteri koliform yang diperoleh yakni tidak berbeda nyata, maka dapat disimpulkan bahwa proporsi beras sejahtera dan sawut singkong tidak memiliki daya hambat pada pertumbuhan koliform pada nasi sawut.

\section{KESIMPULAN}

Perlakuan proporsi beras sejahtera dan sawut singkong memberikan pengaruh 
Versi Online:

http://www.profood.unram.ac.id/index.php/profood e-ISSN: 2443-3446

yang berbeda nyata (signifikan) terhadap kadar air, kadar abu, organoleptik secara hedonik (warna, tekstur dan rasa) namun memberikan pengaruh yang tidak berbeda nyata (non signifikan) terhadap organoleptik secara hedonik (aroma) dan total mikroba. Semakin tinggi proporsi sawut singkong dan semakin rendah proporsi beras sejahtera, kadar air dan kadar abu nasi sawut singkong semakin rendah. Total mikroba nasi sawut singkong pada semua perlakuan menunjukkan hasil yang sesuai dengan standar SNI 7388:2009 yaitu sebesar 1,0 x $10^{6} \mathrm{CFU} / \mathrm{g}$. Total kapang nasi sawut singkong pada semua perlakuan dapat mempertahankan tingkat keamanan sesuai dengan standar menurut SNI 7388:2009 yaitu sebesar $1,0 \times 10^{4} \mathrm{CFU} / \mathrm{g}$. Nasi sawut singkong dengan proporsi beras sejahtera dan sawut singkong (60\%:40\%) merupakan perlakuan terbaik untuk menghasilkan mutu nasi sawut dengan nilai kadar air $(66,02 \%)$, nilai kadar abu $(0,13 \%)$, total mikroba $\left(3,3 \times 10^{5} \mathrm{CFU} / \mathrm{g}\right)$, total jamur $\left(7,2 \times 10^{2} \mathrm{CFU} / \mathrm{g}\right)$, total koliform (27 MPN/g) dan mutu organoleptik yang dapat diterima oleh konsumen.

\section{DAFTAR PUSTAKA}

Amanu, F. N. dan H. S. Wahono, 2014. Pembuatan Tepung Mocaf di Madura (Kajian Varietas dan Lokasi Penanaman) Terhadap Mutu dan Rendemen. Jurnal Pangan dan Agroindustri, 2(3): 161-169.

Aminudin, M. dan I. Habib, 2009. Pengaruh Lamanya Penyimpanan Terhadap Pertumbuhan Bakteri pada Nasi yang Dimasak di Rice Cooker dengan Nasi yang Dikukus. Jurnal Mutiara Medika, 9 (2): 18-22.

Andarwulan, N., Kusnandar, F. dan Herawati, D., 2011. Analisis Pangan. Dian Rakyat. Jakarta.

Badan Pusat Statistik (BPS)., 2015. Kabupaten Lombok Utara Dalam Angka 2015. Badan Pusat Statistik Kabupaten Lombok Utara

Badan Standar Nasional (BSN)., 2009. Batas Maksimum Cemaran Mikroba dalam
Pro Food (Jurnal Ilmu dan Teknologi Pangan)

Vol 6 No. 2 November 2020

ISSN: 2443-1095

Pangan. SNI 7388-2009. Badan Standar Nasional. Jakarta.

Hamdiyati dan Kusnadi, 2012. Mikrobiologi Dasar. Universitas Pendidikan Indonesia. Bandung.

Handayani, B. R., Ridwan., Syarifuddin dan Yuliarti, 2012. Development of Non Rice Product "Cassava Based" in Responding to Climate Change and for Supporting Houshold Food Security in Bayan, North Lombok. Climate Change Adaptation Project.

Haryadi, 2008. Teknologi Pengolahan Beras. Universitas Gadjah Mada Press. Yogyakarta.

Houston, D. F. and Kohler, G. O., 1970. Nutritional Properties of Rice. Natl. Acad. Sci., Washington D.C.

Junaidi, M. S., 2017, The Satisfaction Comparison Of Bantuan Pangan Non Tunai Recipients And Rastra Recipients In Cakung District, East Jakarta. Jurnal IImiah Econosains. 15 (2): 273-288.

Kartika, B., 1988. Pedoman Uji Inderawi Bahan Pangan. UGM. Yogyakarta.

Kusuma, S.A.F., 2010. PCR. Universitas Padjajaran. Bandung.

Leobis, E. H., L. Junaidi dan I. Susanti, 2017. Karakteristik Mutu dan Nilai Gizi Nasi Mocaf dari Beras Analog. Jurnal Biopropal Industri, 8 (1): 33-46.

Luna, P., Herawati, H., S. Prianto, A. B., 2015. Pengaruh Kandungan Amilosa Terhadap Karakteristik Fisik dan Organoleptik Nasi Instan. Jurnal Penelitian Pascapanen Pertanian. 12(1). 1-10.

Mizani, Puti, W. Syarif dan R. Holinesti, 2016. Pengaruh Substitusi Susu Kedelai Terhadap Kualitas Kue Lapis Malaysia. Universitas Padang. Padang.

Pradiptya, A. H. dan Amam, 2019. Analisis Sikap Konsumen Terhadap Produk Olahan Singkong, Jurnal Sosial Ekonomi dan Kebijakan Pertanian, 3 (1) : 19-27.

Purba, J. E., R. J. Nainggolan dan Ridwasnyah, 2017. Karakteristik Sifat Fisiko-Kimia dan Sensori Cookies dari Tepung Komposit (Beras Merah, Kacang Merah dan Mocaf), Jurnal 
Rekayasa Pangan dan Pert., 5 (2): 301-309.

Sabri, M., 2013. Pengaruh Konsentrasi Sawut Terhadap Beberapa Komponen Mutu Nasi Sawut. Skripsi. Fakultas Teknologi Pangan dan Agroindustri Universitas Mataram, Mataram.

Salim, E., 2011. Mengolah Singkong Menjadi Tepung Mocaf. Lily Publihiser. Yogyakarta.

Tandriyanto, 2014. Pengaruh Fermentasi pada Pembuatan Mocaf (Modified Cassava Flour) dengan menggunakan Lactobacillus plantarum terhadap Kandungan Protein. Jurnal Teknik Pomits. 3(2). ISSN: 2337-3539.

Winarno, F.G., 2012. Kimia Pangan dan Gizi. Gramedia Pustaka Utama. Jakarta.

Yadav, B.K. dan Jindal, V.K., 2007. Water Uptake and Solid Loss During Cooking of Milled Rice (Oryza sativa L.) in Relation to its Physocochemical Properties. Journal of Food Engineering. 80: 46-54. 